\title{
The Art of Authenticity: Constantin Stanislavski and Merleau-Ponty
}

\begin{abstract}
Robert F. Mullen
San Francisco, California, USA

Constantin Stanislavski's Russian acting system, further developed by contemporary methodological practices, and Maurice Merleau-Ponty's philosophy of the body as object-subject are compared to illustrate how simple, learned techniques can assist in the production of authentic and transparent interrelational presence. Authentic presence requires three components: (1) honest exposition of a person's singular, essential being; (2) empathy towards the needs of other, distinct and separate from the self; and (3) mutual reciprocation, which means giving back or responding somewhat equitably to the other with whom the self is in communication, and accepting the same respondence from the other if afforded. The comprehension of Merleau-Ponty's ontology combined with Stanislavski's performance technique is uniquely suited to interpersonal communications in the 'real world'. Stanislavski's artistic vision demands an intensity of attentive involvement in order to achieve onstage authenticity. Merleau-Ponty provides supportive philosophical schematics, especially in his controversial but effective use of the expression 'flesh'. While this study may initially appear to focus on the artist, the development of interrelational skills is reliably applicable to anyone who desires to obtain a higher degree of authenticity in collaborative presence.
\end{abstract}

Keywords: authenticity, embodiment, interpersonal, Merleau-Ponty, presence, Stanislavski, subject/object

\section{Introduction}

This study addresses the similarities between Maurice Merleau-Ponty's ontology of the flesh and Constantin Stanislavski's mechanisms for authentic stage presence. As an academic who incorporates 'Method' acting techniques in behavioral workshops, I am uniquely qualified to propose an implicit relationship between Stanislavski's teachings and Merleau-Ponty's ideological framework of subjective/objective interrelationship. Merleau-Ponty underscored embodiment as essential for authentic communication, recognizing acting, art, and literature as catalysts for philosophical investigation. Stanislavski honed his behavioral techniques to train his actors to engage the mind-body-spirit complex ${ }^{1}$ in order to enrich a genuine interconnectedness amongst characters in performance. Both Merleau-Ponty and Stanislavski understood how reciprocation between 'self' and 'other(s)', or subject and object(s) ${ }^{2}$ embellishes the precious and fleeting moments within any relationship,

\footnotetext{
1 The mind-body-spirit complex is the totality of a human person, reflecting the involution of the spirit, and the manifestation of the body, which facilitate the mental progression of consciousness. Each constituent overlaps, influences, and interdepends upon the other, the gestalt containing feelings, emotions, and intellectual thoughts in its more conscious complexities. In quantum mechanics, the mind-body interaction is taken as the interface of conscious intent and unconscious bodily processing. Gobert points out the interaction between the psychology of the actor, the physical body, and his emotions develops entirely in accordance with Cartesian principles of mind-body unity and the passions (Krumholz, 2014).

${ }^{2}$ Herein forward, pluralities of 'other' and 'object' are generally inferred.
} 
and how the interdependency of self and other is a primary conduit to authentic communication.

In-depth understanding of how we, as subject, present our self to other establishes the groundwork for the creation of habits that help us adapt to psychophysiological interpersonal challenges. The body as lived, according to Merleau-Ponty, is an experiential body, one that opens onto a world; it is the intersection between self and other that allows us to belong to the same 'world-body'. It is this presence that facilitates both the perceiver and the perceived, and it is empathy towards and reciprocity within that fosters authenticity: ${ }^{3}$

The first vision, the first contact, the first pleasure, there is initiation that is, not the positing of a contact, but the opening of a dimension that can never again be closed, the establishment of a level in terms of which every other experience will henceforth be situated. (Merleau-Ponty, 1968, p. lii)

\section{Constantin Stanislavski}

Founder of the naturalistic technique of acting, Constantin Stanislavski (1863-1938) originated psychophysical acting, which replaced overzealous stagecraft through a holistic methodology that emphasizes the creation of a mutually beneficial space in order to promote transparency as an aesthetic principle of authentic communication. As herein described, transparency implies opening the 'curtains' to reveal the genuine character of a persona he or she relates to other individuals, with or without the expectation of reciprocity. In real life, we are all actors; the revelation of our true character and intention establishes the foundation for authenticity in presence and communication.

An actor at 14, Stanislavski developed his theatrical skills considerably over time, founding the Society of Art and Literature in 1888, and the Moscow Art Theatre in 1897, while producing plays by Chekhov, Tolstoy, and other classicists. In 1912, he created First Studio, which served as a training ground for young thespians. Stanislavski worked on providing a guiding structure for actors to consistently achieve deep, meaningful, and disciplined performances (Stanislavski, 2015, p. 1). He believed that actors need to embrace authentic emotion, drawing upon feelings experienced in their own lives, rather than attempting to 'fake it' while performing on stage.

Never content to rest on his laurels, Stanislavski "continuously reviewed and attempted to convey more exactly the substance of his insights, discoveries, conclusions" (Hobgood, 1973, p. 150). In later studies, attention has been directed to Stanislavski's philosophy of embodiment and nonduality. In his adaptation of the efficacy of incorporating the mind-body-spirit complex into acting technique, Stanislavski underscored the indivisible unification of "the psychological and the physical in the human being" (Moore, 1965, p. 92), requiring his students to "practice exercises in voice, diction, rules of speaking, and bodily relaxation", and urging them "to participate in various types of sports to develop physique, agility, and improve timing" (Norvelle, 1962, p. 33). As his techniques matured, Stanislavski began to emphasize physical action over the emotional in his Pavlovian methodology in order to "create the need for that inner life which permits an actor to realize the external action" (Coger, 1964, p. 67).

\section{Maurice Merleau-Ponty}

According to biographer Barral (1983), Maurice Merleau-Ponty (1908-1961) was an enigmatic, phenomenological philosopher concerned with uncovering the ground of an individual's perceptual being by

\footnotetext{
${ }^{3}$ A person of authenticity is one who lives in accordance with his or her desires, motives, ideals, or beliefs, and whose sum of intents and actions are thus manifest as beneficial to self and society.
} 
clarifying the relationship of the body to the world. "He unmistakably discovers also that relation which, arising from the obscure and mysterious depths of being, blossoms forth in the end, into a fully human and personal exchange" (Barral, 1983, p. 155). The philosopher's theory on the interrelationship of corporeal bodies-what he termed the 'flesh' or the concrete element of being - is a predominate theme that facilitates the building of authentic presence in communication through subjective experience and experiencing, and objective embracing of the other's experience and experiencing.

Merleau-Ponty's consideration of the body as an object lays the grounding for the transformation of one's subjective nature into a complimentary awareness of an objective world which exists 'out there'. In this world of 'out there', the self shares the space in reciprocity with other, as both become transmitters and receptors. Although situated within our own environments, our conditional free will provides the opportunity to act on circumstance in established supportive and caring presence. However, the self is only a partial constituent to interaction; it cannot effect interpersonal authenticity without the dual-reciprocating force of self and other, which demands acknowledgement of mutual motivation and desire. Genuine interrelationship is always situated by motivation in an environment in constant flux. Merleau-Ponty "emphasizes that the other is always already encroaching upon us, though they are not reducible to us, and ... the risk of this overlapping with the other can and should always be there"4 (Reynolds, 2005, p. 10).

While this study makes general comparisons to the methodologies and philosophies of Stanislavski and Merleau-Ponty, it by no means concludes a total coalescence. Whereas Stanislavski is obsessed with the individual actor's awareness of the internal/external connection for the purpose of performance, Merleau-Ponty is more responsive to the bodily relationship between individuals and objects in general. To those who question the veracity of what I am proposing, my response is that I have acquired these ideas during extensive 'method' participation and philosophical study. My conclusions are both experiential and academic, offered not as proven fact but as plausible hypothesis. The proposed relationship between the concepts of Merleau-Ponty and Stanislavski may sometimes appear moderately heterodox but is certainly not groundless.

\section{Presence, Authenticity, and Interrelationship}

For purposes of this comparison, 'presence' is defined, simply, as the condition of one entity in a space; a correlational presence is two or more entities in a space, likewise the self sharing the same space in conjunction with another. It's also important to understand the meaning of authenticity as used herein. Taking into consideration the interpretations of Rousseau, Kierkegaard, Heidegger (dasein), Ferrera, and others, the concept of authenticity useful for this study is that of metaphysical, and anthropologic understandings of the self which value individual worth as concomitant with the good of others (society). ${ }^{5}$ A person of authenticity, being true to self, is one who undergoes a personal transformation through introspection and inner discourse in order to live in accordance with his or her desires, motives, ideals, or beliefs, and whose sum of intents and actions is thus manifest as beneficial to self and society. Sartre tells us that the human person is responsible for everything he or she does, and "when we say that man is responsible for himself, we do not mean that he is responsible only for his own individuality, but that he is responsible for all men" (1989, p. 4). In spite of the circumstances to which he or she is subjected, the authentic person responds with a notion of excellence in

\footnotetext{
${ }^{4}$ Merleau-Ponty, M. (1968, p. 123).

5 Some of the concepts of authenticity are evolved from Varga, S. and Guignon, G. (2014).
} 
moral virtue (arête), ${ }^{6}$ accepting total responsibility for self-intent and action. A person who assumes responsibility does not willingly subordinate his or her will to that of another, deific or otherwise, as the act of consigning responsibility is a capitulation of the extraordinary power and will of the self, denying the power of choice and rendering it ineffectual.

One also comes to a new understanding of responsibility. Where before one was primarily in a denying or blaming stance toward oneself, now there is the honest acknowledgement of one's participation in the event. (Bauer et al., 1992, p. 158)

Authentic presence requires three components: (1) the honest exposition of a person's singular, essential being, (2) empathy towards the needs of other, distinct and separate from the self, and (3) mutual reciprocation, which means giving back or responding somewhat equitably to the needs and motivations of the other with whom the self is present, and accepting the same respondence from the other if afforded.

In focusing on the interrelationship of self to other, this study allows that, as individuals, we must remain cognizant of our integral relationship with other, a truth not lost on Stanislavski who stressed the social character of the collective undertaking of his actors. Any attempt to separate the multivalent constituents of self from those of other mitigates the quality of the presence and communication; one's authenticity is a product of interconnected parts including the subjective and the objective.

Emphasis on the use of the word 'interrelationship' over relationship is important. A weed has a relationship to the rosebush in which it is intertwined; a duck must have a relationship to the water upon which it floats; and a human being can have a relationship to a myriad of objects, colors, smells, tastes, and etcetera. An interrelationship, both by definition and in the context of this study, connotes mutuality between relationships, an altruistic reciprocation-taken from the Latin word reciprocus, - a returning the same way, alternating. This mutually corresponding interrelationship is, by nature, disproportionate, which affects the integrity of the communication but does not necessarily weaken the authenticity.

\section{Embodiment}

To embody something is to embrace through the absolute and tangible coalescence of the mind-body-spirit complex. It is the act of incorporating the corporeal, spiritual, and mental faculties into all efforts at presence a communication-on stage as well as in the everyday world 'out-there'. Stanislavski realized this when he established what he called his "psychophysiological approach through embodiment and the shaping of 'energy' ... an extension of [his] early, innovative use of the compound term 'psychophysical"” (Zarilli, 2007, p. 637). For Merleau-Ponty, embodiment is a major factor in his unfinished, The Visible and the Invisible (1968), where he elaborated on his conception of the gestalt, the chiasmic intertwining of constituents that make up the self-as-perceiver's totality through the interrelationship of the psychophysiological, and spiritual. ${ }^{7}$ Through innate structure, basic general competence, and inculcated social and cultural skill, our bodies determine what we present to the world. "The lived body as a gestalt is present as an intersecting, intertwining, chiasm of multiple bodies” (Zarilli, 2004, p. 665). As a gateway to authentic performance, Merleau-Ponty's phenomenology:

\footnotetext{
${ }^{6}$ In Plato's Meno, arête is expressed as moral virtue, which to Socrates, is the notion of excellence in the fulfillment of purpose-the act of living up to one's full positive potential. See Gutherie, W. K. C. (1956).

By spiritual, I refer to one's inner fortitude (or, perhaps, the perfect homeostasis of mind and body) rather than a dogmatic relationship to an enigmatic, unapproachable, and incomprehensible deity.
} 
... is, arguably, one of the most appropriate methodologies to utilize when considering acting, since it does not begin with performance as the object of inquiry, but foregrounds the 'lived' embodied experience of the practitioner as central to its project. (Zarilli, 2007, p. 641)

Embodiment, in Merleau-Ponty's thinking, is less about calling attention to the mind-body-spirit complex, than emphasizing the function of the body as the observable locus that embraces the participation of the mind and spirit through the phenomenological 'lived body' - the subjective body as lived by experience. The infrastructure of embodied communication, the psychobiological and physical presence of our bodies is a necessary precondition for the subjectivity of thought, emotion, language, social interactions, ad infinitum. The self (actor) must be both subjective (having experienced and experiencing) and objective (embracing what the other has experienced and is experiencing).

\section{The Inner Creative State}

"Art lends beauty and nobility to presence, and whatever is beautiful and noble has the power to attract" (Stanislavski, 1949, p. 248). The Russian master proposed that we "learn to draw our spiritual, organic natures into our creative work". He universalized this staged embodiment by making "it crystal clear that 'creativeness' is the result of the actor being able to concentrate, to bring his body, mind, and soul under thorough concentration" (Norvelle, 1962, p. 31). Philosopher Duane Davis (1991) proposes that "speech, written discourse, and gesture all permit some sort of transcendence whereby I can be said to 'get outside of myself" (as cited in Erdinast-Vulcan, 2007, p. 400). The product of genuine creativity connotes dynamism, a surpassing, exceeding and/or reconstituting, a 'going above and beyond' ordinary limits.

Merleau-Ponty embraced "the visual arts and ... literature not as an illustration or sublimation of philosophical concerns, but as the very material of philosophical investigation and the source of its insights" (Erdinast-Vulcan, 2007, p. 400). Stanislavski believed that: "At the heart of every unit (moment) lies a creative objective" (1936, p. 127). Art is search, not final form; creativity is a philosophical constant. "The creator must give a part of life — in fact, his own life —in order to make it eternal in his work of art" (Rank, 1932, p. 293). Art requires a continuing evolution of methodology in order to better embrace the concerns of humanity through the sharing of expression. Art does not stand alone but is a collective bestowing by means of experience and expansion. It is this understanding of collectivity-of allocating the visionary presence of the self with other-that imbues the art and creator with growth. "Stanislavski believed in two sources of material for an actor's creative work: the inner life of an actor himself and his observation of the outside world-an inexhaustible source" (Moore, 1960, pp. 43-44). Stanislavski understood what he called the Super-Objective of art, which is "the essence of the immediate relationship" and "the reconnaissance of the mind" (Moore, 1960, p. 51). This interdependent relationship might be mechanical (habitual), ordinary (with expression of emotion), or analytic (as result of thoughtful analysis); sufficiently enhanced, each is a springboard for authentic and loving communication. "All [creative] action ... must have an inner justification, be logical, coherent and real" (Stanislavski, 1936, p. 49). Translating to real life, authentic presence and communication is underscored by the same inner justification through the adoption of a deeper intimacy between self and other by way of empathetic observation, reciprocity, and learned listening skills; anything less is disingenuous.

\section{Intention}

Just as the actor is motivated to search out the inner purpose of his or her character, so must the self-in 
order to find true authenticity-empathetically research the other, analyzing situation and motivation with the will to do good as objective. David Katz stresses "that 'good' refers to such characteristics as regularity, symmetry, inclusiveness, unity, harmony, maximal simplicity, and conciseness" (1950, p. 40). If one wishes to communicate well, to create a homeostasis and inclusiveness with the other-to authenticate the relationship—one has to work diligently to rehabituate inherent selfishness by honing a positive and altruistic inner motivational force. As Stanislavski wrote: "A first-class musician should never play on an instrument out of tune" (1949, p. 134). We want to control a safe perception of our individuality by hiding behind carefully-crafted facades, but embracing genuine intercourse through a courageous willingness to expose our self to inner-and-outer-truth is the only answer to true communion. As Merleau-Ponty points out:

Once the other's gaze fixed upon me has, by inserting me into his field, stripped me of part of my being, it will readily be understood that I can recover it only by establishing relations with him, by bringing about his clear recognition of me. (1962, p. 426)

This stripping away of pretense-the deception constructed to cocoon the fear of the self perceived as fraudulent-is paramount to authenticity. We must knowingly and willingly transmit the values of the human spirit. "The true is the objective" (Merleau-Ponty, 1968, pp. 14-15).

As in any presence between self and other, each participant has some basic purpose in the situational circumstance. In acting, as in life, "such a purpose is called central action, and reflects the character's most important strivings" (Moore, 1960, p. 50). This means that the self must be knowledgeable and accepting of the needs and inclinations of other. It is impossible, in authentic communication, to cooperate in an action without concern for the needs and motivations of all participants. Barral informs that "intersubjectivity and interpersonal relations are totally dependent on our choice and decision and involve every kind of encounter in any aspect of life" (1983, p. 158). Merleau-Ponty "insists that we do not make the world that we experience" (Flynn, 2004, p. 8), but once party to that experience, we make of it what we will in the world, as experience is composed of ourself and other with whom we interact. The interdependency of self and other is a conduit of feelings and perceptions that overlap and intertwine "without ever being reduced to each other" (Reynolds, 2005, p. 9); individuality remains fluid but intact. Producing a transparent and total presence requires a commitment of all parties to the shared space. Are our motivations altruistic for the betterment of the interrelationship or do we communicate to boast of ourselves or to vent without concern for the needs of the other? "Generally speaking, this question — for what reason? - is extremely important. It obliges you to clarify the object of your meditations, it suggests the future, and impels you to action" (Stanislavski, 1936, p. 74).

\section{Method Exercises}

The following practices from Stanislavski's methodology were primarily created for the purpose of incorporating authenticity in stage performance through reciprocity, empathy, subjective-objective-transference, emotional recall and control, positive rehabituation, and etcetera. It is my position that the same exercises can be employed for the purpose of discovering and establishing improved authenticity in personal and worldly interaction. On an experiential level, I can attest to the efficacy of such exercises, in tandem with other methodologies, in workshops created to address issues related to social anxiety, self-esteem, authentic communication, and other concerns. 


\section{Adaptability}

Exercise \#1: The actor improvises a situation with other actors, then adapts his or her character to the immediate needs of the other, as well as the needs of the self in relationship to the needs of the other as the circumstances, character, and plot improvisationally evolve.

We shall use this word, adapt, from now on to mean both the inner and outer human means that people use in adjusting themselves to one another in a variety of relationships and also as an aid in effecting an object ... it is a vivid expression of inner feelings or thoughts ... it can call the attention to you of the person with whom you wish to be in contact ... it can prepare your partner by putting him in a mood to respond to you [and] it can transmit certain invisible messages, which can only be felt and not put into words. (Stanislavski, 1936, p. 242)

According to Stanislavski, the artist (actor/self) is created through an energy that "operates not only inside us but outside as well, it wells up from the depths of our beings and is directed to an object outside ourselves" (1949, p. 63). For an actor, every word, activity, or emotion,

... requires an intangible form of adjustment all its own ... but it will be in an infinite variety of combinations of objectives, and given circumstances ... which have been smelted in the furnace of your emotion memory. (Stanislavski, 1936, p. 192).

In life, as on the stage or the writer's page, "the choice of actions, then, is the foundation on which a character is built" (Moore, 1960, p. 56). However, no matter the preparation, every situation is subject to impermanence, which must be met with flexibility. Piaget advises that: "So long as there are no permanent objects, everything is a change of state" (1971, p. 17). In learning to adapt through continued and rigorous exercise, the actor is trained in plasticity, cultivating the ability to adjust to new and unexpected situations, which facilitates an intuitive, immediate reaction to other, to situation, and to circumstance. "There is no direct approach to our subconscious, therefore we make use of various stimuli that induce a process of living the part, which in turn inevitably creates inter-relationship and conscious or unconscious adjustments" (Stanislavski, 1936, p. 258). Within the 'real world' of interrelationships, the ability to control our adjustment to the fluctuations of other is greatly enhanced by this and comparable models of this exercise.

\section{Breaking the Chains}

Exercise \#2: The actor is asked to visualize hypothetical situations. "Imagination creates things that can be or can happen, whereas fantasy invents things which are not in existence. ...And yet, who knows, perhaps they will come to be" (Stanislavski, 1936, p. 60).

We are all emotionally entangled with the sins of our fathers and our consequential, self-imposed, habitual habits-impediments to our ability to share authentic presence. The primary goal of this method acting technique is to break the patterns of habitual negative mannerisms and reactions in order to create novel and genuine ways of being and relating. Erdinast-Vulcan writes:

As perception becomes habitual, it also becomes automatic and unconscious; our daily routines are based on "learning to ignore" - we hardly notice ourselves performing habitual actions; we no longer really see our surroundings; we go about our daily business almost as if we were blindfolded. (2007, p. 403)

Likewise, most of us are habitually responsive to situation and circumstance. Developing our behavioral response beyond the negative and reactionary can only benefit the depth and truthfulness of interpersonal communication. The initial object of method acting is the awareness, use, and control of one's emotions in 
reaction to circumstance and situation-delivering fresh spontaneity through modified habits underscored by practical response.

A habit is an aptitude for responding to a particular type of situation with a particular form of solution. This habit as an operation is both bodily and spiritual. It is an existential operation. (Merleau-Ponty, 1982, p. 52)

To what degree the chains of past experience are loosened is facilitated by the efforts of the practitioner. When the aesthetic pleasure of intimacy is trivialized by negative habituation, our 'beingness' in correlational presence is bereft of authentic meaning. Victor Shkolvsky, art critic and contemporary of Stanislavski wrote, "art exists that one may recover the sensation of life; it exists to make one feel things" (1917, p. 403).

There are numerous memory and emotional-recall exercises employed in training an actor to cut-through the restricting habits that inhibit the ability to honestly portray a character. It is an overriding premise of this study that these method exercises are effective means of reconstruction, applicable to negotiating the world-at-large. We are all born with authenticity, but the living experience ostensibly corrupts. "The redeeming role of art is to 'defamiliarize', to de-automatize, to restore and revive the sensation and the value of life through a disruption of mechanical and habitual modes of perception" (Erdinast-Vulcan, 2007, p. 403). The method actor prepares for a variety of roles through a process of self-development via psychophysiological exercise, behavioral study, and stagecraft, which not only informs the character but is transferable and transformative to real life. As a result of these practices, the actor is subject to a gradual maturation of authentic presence and communication. The self learns to live 'in the moment' through this acquired authenticity which can supersede a lifetime of selfish and negative response. Merleau-Ponty explains:

The operative language, that of literature, of poetry, of conversation, and of philosophy, which possesses meaning less than it is possessed by it, does not speak of it, but speaks it, or speaks according to it, or lets it speak and be spoken within us, breaks through our habitual present. (1968, p. 126)

\section{Modifying Habits}

Exercise \#3: The actor is directed to focus attention on various objects on the stage while concentration is constantly shaken by a cacophony of distractions-competing metronomes, fluctuating aspects of lighting, extraneous actors, and other factors. This emphasizes the essentialness of control, intensity of purpose, and concentration-the solidification of motivation within a situation that is subject to variables.

Merleau-Ponty evokes the simple experience of seeing a spot of light on a wall in a dark room. In this situation, the subject speaks of his attention being attracted by a spot of light, of his being pulled along by it. As such, this behavior is teleological and meaningful; it has a direction. (Flynn, 2004, p. 2)

Stanislavski compares the artist's all-consuming involvement in his or her craft as something of an Eleusinian mystery. "The real passion lies in the poignant acquisition of knowledge about all the shadings and subtleties of the creative secrets" (Stanislavski, 1949, p. 251). These secrets are revealed through intensive psychophysiological processes-the development of the mind-body-spirit complex through introspection, discovery, practice, and an inculcation of novel experiences that engender new perceptions, moods, feelings, intentions, and associations. Piaget writes:

If all knowledge is always in a state of development and consists in proceeding from one state to a more complete and efficient one, evidently it is a question of knowing this development and analyzing it with the greatest possible accuracy. This becoming does not unfold itself as a matter of chance but forms a development. $(1971$, p. 6) 
All of the methods described herein are mechanisms that, when practiced with courage and intensity, can lead to the establishment of adaptable modes of authentic operation both onstage and in the world 'out there'.

\section{Somatic Communion}

Exercise \#4: The actor is directed to imitate characters possessed of diverse motivations such as those of a pederast, thief, politician, and etcetera. This method of somatically residing within another's physical or mental situation accustoms the actor to different situational and emotional realities. Stanislavski described the brain and the solar plexus as dual centers of personal communication. Citing his understanding of the Sanskrit word, 'prana' (breath, vital life force), he "felt as if he had two I's which established a steady dialogue between themselves as if they were two actors" (Moore, 1965, p. 36). Stanislavski understood these dualities as two interrelating components of a single entity: the cerebral center as the seat of consciousness, and the nerve center (the solar plexus), the seat of emotion. "The sensation was that my brain held intercourse with my feelings. I was delighted because I had found the subject and the object for which I was searching” (Stanislavski, 1936, p. 215).

For Merleau-Ponty, also, the mental and corporeal cannot be understood as competing commodities, but must be taken as a singular subject-object. Krumholz reminds us that, in contradiction to the Cartesian concept of mind and body as disconnected $(2014$, p. 3$),{ }^{8}$ Descartes understood that, in real life, the body can exist without the mind, but it cannot experience or be experienced.

The very concept of the actor's interiority, so central to modern acting as we have come to know it, would not be possible without the seed of Descartes's newly-fashioned subjectivity, the "I" who is able to reflect upon his own being. Furthermore, Gobert is sure to point out that the interaction between the psychology of the actor, the physical body, and his emotions develops entirely in accordance with Cartesian principles of mind-body unity and the passions. (Krumholz, 2014, p. 2)

The body as lived is an experiential body, one that opens onto a world and allows the world to do likewise. "We are best served by referring to the individual as not simply a body, but as a body-subject" (Reynolds, 2005, p. 3). Our 'being' and that of the other overlaps and intertwines by means of sensation which connects us and other things around us through a reciprocating relationship; we feel the world because it feels us. And within this chiasm, according to Merleau-Ponty:

We all reach the world, and the same world, and it belongs wholly to each of us, without division or loss, because it is that which we think we perceive, the undivided object of all our thoughts. Its unity, if it is not the numerical unity, is not the specific unity either: it is that ideal unity or unity of signification that makes the triangle of the geometer be the same in Tokyo and in Paris, the same in the fifth century before Christ and now. (1968, p. 31)

Perception gets us in touch with sensations as we make intimate contact with the things perceived. We are inextricably intertwined with the things in our vision. In fact, it is only on the basis of our perception already intermixed with the things it sees that we are able to see them. It is not as though things are completely independent to us, and then we see them. Instead, we are already in touch with them from the beginning; we share the same 'flesh'. The chiasm or intersection between perceiver and perceived, according to Merleau-Ponty, is what allows all of us to belong to the same world, the same body, while maintaining opposing relations. The 'chiasm' is a functioning of self and other, in other words, a codependent and

${ }^{8}$ Referencing Gobert (2013). 
intertwining 'we'. Merleau-Ponty argues "that it is essential that the seer itself be visible, that is, seeable" (Flynn, 2004, p. 20). Capitalizing on the very essence of transparency in presence, "the Body is now understood solely through the notion of that which is simultaneously both sensing and sensed" (Falk, 1970, p. 279).

Phenomenologist David Abram explains Merleau-Ponty's concept of flesh as "the mysterious tissue or matrix that underlies and gives rise to both the perceiver and the perceived as interdependent aspects of its spontaneous activity" (1996, p. 66), and he identifies this elemental matrix with the interdependent web of earthly life. This concept unites subject and object dialectically as entities within a more universal reality, which Merleau-Ponty calls the 'flesh' and which Abram refers to variously as 'the animate earth', 'the breathing biosphere' or 'the more-than-human natural world' (1996, p. 65). For Merleau-Ponty, the body is a living organism by which the self thrusts or emerges its intentionality into the world. The energy of the existence of self is experientially lived through the body. Merleau-Ponty described the body as flesh, made of the same flesh of the world, and it is the result of this mutuality that we can know and understand the world as it pertains to self and other. The pervading motivation of Merleau-Ponty's body as subject-object is to attempt a reconstruction of philosophy from the ground up. In order to advance this thinking, he embraces theater, literature, and visual arts as the ground of philosophic interrogation and the source of its homeostasis. The obvious benefit to non-performance situations within the 'real-world' is empathetic intent and action. Atticus Finch conveyed that supreme recognition in To Kill a Mockingbird: "You never really know a man until you understand things from his point of view, until you climb into his skin and walk around in it" (Lee, 1960).

\section{Perception}

Exercise \#5: The actor is asked to focus on a 'small circle of attention'-a table, for example-which holds a number of objects. The actor is then directed to describe the items from memory. The exercise is repeated with a 'medium circle of attention', which includes one or two other actors and their surroundings. Eventually, the area expands to a 'large circle of attention', to include the entire stage. As the actor begins to waver within the chaotically larger circle of attention, "he is advised to [visually] withdraw quickly to a smaller circle" (Stanislavski, 1936, p. 92). But because of the perceptual distractions of competing circles of attention, the actor's attention begins to flounder and dissipate even with renewed effort. Stanislavski realized that his students were perceiving themselves as the center of attention: they were actively situating themselves in the space rather than passively (subjectively) experiencing the space as observer. In other words, their subjective needed to embrace their objective in order to fully embrace all spatial zones. Of course, that subjective-objective perception is different for each participant. For Merleau-Ponty, this exercise underscores the threshold of transcendental philosophy. Merleau-Ponty argues that the gestalt exists for the perceiving subject; it does not exist for any other subject but is the sole domain of the subject-perceiver, whose world that extends beyond is the subject's perception of the subject's own experience and frame of reference. "When I say that I see the ash-tray over there, I suppose as completed an unfolding of experience which could go on ad infinitum, and I commit a whole perceptual future" (Merleau-Ponty, 1962, p. 421). The world has signification only because it has direction within our experience, and that experience must be both subjective and objective. Every localization of objects in the world presupposes one's own locality. "In a sense, an object of perception continually speaks to us of ourselves", according to Merleau-Ponty (1982, p. 36). "As incarnate subjects, we are expressed by the object". Flynn (2004) reasons that, in perception, the self discovers a sense which is not self-constituted, while Merleau-Ponty recognizes that: "perception operates on the basis of my relationship to 
the world" (1982, p. 37). That is why it is so essential for the actor to walk 'in the shoes' of the other interacting characters, and so essential for each of us to emphatically relate and respond to the other. While this particular comparative relationship between Stanislavski and Merleau-Ponty is, admittedly, a slightly unorthodox reconstruct of their intentions, I argue its resonance.

Method acting can cultivate a clearer acuity of self and other in circumstances that reinvigorate the individual's capacity for authenticity. Heightened perception and awareness lends genuineness (caring) to the interrelationship. Merleau-Ponty understood perception as a "totality open to a horizon of an indefinite number of perspectival views which blend with one another according to a given style, which defines the object in question" (1964, p. 16). The French philosopher employed the word 'flesh' as the origin of being that regulates and augments both the perceiver and the perceived in spontaneity. "The body is both the perceiver and the perceived, the unifier and the unified ... in the progressive unfolding of meaning, from childhood" (Barral, 1983, p. 155). In his book on the social phenomenology of Merleau-Ponty, O’ Neill states that:

The theory of the body image is, implicitly, a theory of perception. The phenomenal body is a matrix of human existence. It is the center around which the world is given as a correlate of its activities. (1970, p. 13)

A self in the presence of other in everyday life will experience perspectives in constant flux as the other moves, changes subject, and communicates with additional other. Since nothing remains constant, the maintenance of authentic presence requires practice in modifying expectations and comfort-zones to accommodate these continued fluctuations of the other with which the self is communicating and, also, fluctuating in response to change and anticipation of change.

\section{Self-awareness and Reflection}

Exercise \#6: "Our whole creative experiences are vivid and full in direct proportion to the power, keenness and exactness of our memory" (Stanislavski, 1936, p. 202). To this end, the actor is directed to appear alone on stage to practice affective memory through 'the emotion exercise'. The director instructs the actor to re-experience events of sadness, joy, pride, fear, and anger-emotions which have already been repeatedly practiced. During the exercise, the actor does not know which emotion the director will request but all five are utilized in rapid-fire succession as the actor learns to flip the emotional switch at will. The exercise instills upon the actor the realization that emotions are transitory and controllable, quick to appear and easily extinguishable.

That is what it is like in the archives of your memory. It has all those divisions and sub-divisions. Some are more accessible than others. The problem is to recapture the emotion that once flashed by like a meteor. (Stanislavski, 1949, p. 188)

This immediate sensory retrieval is important for maintaining control over one's emotions both in performance and in everyday life; it allows the self to reflect on situations repressed or impressionable, plumbing the depths of personal feelings, vivifying or subjugating them. ${ }^{9}$ It is an invaluable exercise for anyone willing to embrace the multivalence of self and other. In order to authentically engage, the self must always take into consideration the impermanent and chronic fluctuations of emotion. True authentic interaction

\footnotetext{
${ }^{9}$ Stanislavski later determined that a physical repetition of events often provided the actor more oversight than its emotional counterpart, an effective modification of the interrelationship within the mind-body-spirit complex, placing the importance of the physical over the emotional. "[Stanislavski] dispensed with emotional recall because the use of physical action evoked the needed emotive content [in an] attempt to find means which the actor can control and through which he can summon the necessary unconscious experience, rather than evoking emotions which then must be sorted and controlled" (Coger, 1964, p. 67).
} 
calls for the self's immersion into the perceptions of the other through subjective-objective transference. It is here that the self discovers its own reflection which, as Merleau-Ponty explains:

... must plunge into the world instead of surveying it, it must descend toward it such as it is instead of working its way back up toward a prior possibility of thinking it — which impose upon the world in advance the conditions for our control over it. It must question the world, it must enter into the forest of references that our interrogation arouses in it, it must make it say, finally, what in its silence it means to say. (1968, pp. 38-39)

Only through awareness of one's own emotions as reflected by the other can one truly achieve authentic interpersonal communication. "You can see from this that we use not only our own past emotions as creative material but we use feelings that we have had in sympathizing with the emotions of others" (Stanislavski, 1936, p. 205). Empathy and reciprocity are fundamental components of the unique and enigmatic structure which is 'presence'-the phenomenological intersection of the perceiver and the perceived. It remains the role of the self-as-perceiver, to accommodate the fluctuating emotions of the other-as-perceived-emotions also expressed through spontaneous body movement in gestures which naturally accompany communication. A shrug of the shoulder, a twitch of the spine, each mobility expresses the mental processes; our bodies expose what we are thinking and experiencing, often, well before we are aware of it.

My movements and the movements of my eyes make the world vibrate - as one rocks a dolmen with one's finger without disturbing its fundamental solidity. With each flutter of my eyelashes a curtain lowers and rises, though I do not think for an instant of imputing this eclipse to the things themselves; with each movement of my eyes that sweep the space before me the things suffer a brief torsion, which I also ascribe to myself; and when I walk in the street with eyes fixed on the horizon of the houses, the whole of the setting near at hand quivers with each footfall on the asphalt, then settles down in its place. (Merleau-Ponty, 1968, p. 7)

In authentic presence, a common ground is constituted between the self and other, all thoughts interwoven into a single fabric. Our actions and words, and simultaneously those of whom we are interrelating, are called forth by the state of the discussion, and they are inserted into a shared operation ... we are collaborators for each other in consummate reciprocity (Merleau-Ponty, 1962, p. 416). It is the flesh, a concrete element of 'being', that unites the perceiver with the perceived, first through perception, "then through communication at the various levels of conscious exchange through language, art, sexuality" (Barral, 1983, p. 156). Become one with the other with whom your self is communicating. "Insinuate yourself into [the] very soul [of the other], and you will find yourself the more infected for doing so", Stanislavski advised. "And if you are infected everyone else will be even more infected" (1949, p. 123). We are actively involved when speaking, looking, listening, and reflecting the other, simultaneously anticipating and evaluating the other's own reflection and the other's reflection of us. As perceiver, the self is never passive while listening; the other's words and gestures become a window through which the self sees its own thoughts. The capacity for seeing depends upon the capacity for being seen-that is, according to Reynolds (2005, p. 3), being physically embodied in what Merleau-Ponty "has described as an 'inter-individual' world"”.

\section{Conclusion}

Both Stanislavski and Merleau-Ponty underscore that authenticity of presence and communication is best effected though cognizance of how the self responds to the other-psycho-physiologically with spiritual inner-strength and determination. Although the concept of embodiment is behavioral and habitual to Stanislavski, and phenomenological to Merleau-Ponty, both are experiential-the consequence of 
interdependency and authenticity the similar goal. This interconnection of 'beingness' is built upon perceptual adaptation, the ground for the relationship of the body to the world. Merleau-Ponty's ontology of the flesh complements Stanislavski's demand for authentic presence on stage-both useful in understanding and rendering genuine and legitimate presence in communication. Merleau-Ponty underscored embodiment as an element of authenticity, recognizing art and literature as catalyst for philosophical investigation. Stanislavski honed his behavioral techniques to focus his actors on the necessity of engaging the mind-body-spirit complex in order to enrich a genuine interconnectedness within performance. They both understood how the interdependency of self and other is a conduit to perceptions and emotions that intertwine and overlap. In-depth experiencing of the world exposes this interrelationship, and sets the groundwork for the creation of habits that help us adjust to different psychophysiological challenges. The body as lived, according to Merleau-Ponty, is an experiential body, one that opens onto a world and allows the world to do likewise, and it is the intersection between self and other that allows us to belong to the same 'world-body', while maintaining individuality and its opposing relationships. It is a presence that facilitates both the perceiver and the perceived, and it is empathy and reciprocity that fosters authenticity. As Merleau-Ponty suggests, "Everything transpires as if the other person's intuitions and motor realizations existed in a sort of relation of internal encroachment, as if my body and the body of the other person together formed a system" (1982, p. 52). For him the body is not a machine, but a living organism by which we assimilate our possibilities in the world. "In the last resort, the actions of others are, according to this theory, always understood through my own; the 'one' or the 'we' through the 'I"' (Merleau-Ponty, 1962, p. 406).

\section{References}

Abram, D. (1996). The Spell of the Sensuous: Perception and Language in a More-Than-Human World. New York City, NY: Pantheon Books.

Barral, M. R. (1983). Merleau-Ponty and Psychology. Highlands, NJ: Humanities Press.

Bauer, L., Duffy, J., Fountain, E., Halling, S., Holzer, M., Jones, E., Leifer, M., \& Rowe, J. O. (1992). Exploring Self-Forgiveness. Journal of Religion and Health, 31(23), 149-160. Retrieved from http://www.jstor.org/stable/27510687

Biography.com Editors. (2015). Constantin Stanislavski. The Biography.com website. Retrieved from http://www.biography.com/people/constantin-stanislavski-9492018

Coger, L. I. (1964). Stanislavski Changes His Mind. The Tulane Drama Review, 9(1), 63-68. Retrieved from http://www.jstor.org/stable/1124

Davis, D. H. (1991). Reversibly Subjectivity: The Problem of Transcendence and Language. In M. C. Dillon (Ed.), Merleau-Ponty Vivant. Albany, NY: State University of New York Press.

Erdinast-Vulcan, D. (2007). That Which Has No Name in Philosophy: Merleau-Ponty and the Language of Literature. Human Studies, 30(4), 395-409. DOI: 10.1007/s 10746-007-9069-2. $\quad$ Retrieved from http://www.jstor.org.ezproxy.sfpl.org/stable/pdf/27642810.pdf?acceptTC=true

Falk, B. (1970). A Review of the Visible and the Invisible. The Philosophical Quarterly, 20(80), 278-279. DOI: 10.2307/2218411. Retrieved from http//www.jstor.org/stable/1338758

Flynn, B. (2004). Maurice Merleau-Ponty. Stanford Encyclopedia of Philosophy. Retrieved from http://plato.stanford.edu/entries/merleau-ponty/

Gobert, R. D. (2013). The Mind-Body Stage: Passion and Interaction in the Cartesian Theater. Theatre Research in Canada/Recherches théâtrales au Canada. Toronto: Centre for Drama, Theatre \& Performance Studies.

Gutherie, W. K. C. (1956). Protagoras and Meno. In R. D. Allen's (Ed.), Greek Philosophy. Thales to Aristotle. New York: The Free Press.

Hobgood, B. (1973). Central Conceptions in Stanislavski's System. Educational Theatre Journal, 25(2), 1347-1359. Baltimore, MD: The Johns Hopkins University Press. Retrieved from http://www.jstor.org/stable/3205864

Katz, D. (1950). Gestalt Psychology. New York City, NY: Ronald Press. 
Krumholz, B. (2014). R. Darren Gobert. The Mind-Body Stage: Passion and Interaction in the Cartesian Theater. Theatre Research in Canada 33(3), 1-3. Stanford: Stanford University Press. Retrieved from https://journals.lib.unb.ca/index.php/tric/article/view/22394/26053

Lee, H. (1960). To Kill a Mockingbird. Philadelphia, PA: J.B. Lippincott \& Co.

Merleau-Ponty, M. (1962). Phenomenology of Perception. New York City, NY: Routledge.

Merleau-Ponty, M. (1964). The Primacy of Perception. Chicago, IL: Northwestern University Press.

Merleau-Ponty, M. (1968). The Visible and the Invisible. Evanston, IL: Northwestern University Press.

Merleau-Ponty, M. (1982). Merleau-Ponty \& Psychology: Studies in Existential Psychology and Psychiatry. Highlands, NJ: Humanities Press.

Moore, S. (1965). The Method of Physical Actions. The Tulane Drama Review, 9(4), 91-94. Retrieved from http://www.jstor.org/stable/1125034

Moore, S. (1960). The Stanislavski System. London, England: Penguin Books.

Norvelle, L. (1962). Stanislavski Revisited. Educational Theatre Journal, 14(1), An Issue Devoted to Acting and Directing, 29-37. Baltimore, MD: The Johns Hopkins University Press Stable. Retrieved from http://www.jstor.org/stable/3204712

O’Neill, J. (1970). Perception, Expression, and History: The Social Phenomenology of Maurice Merleau-Ponty. Chicago, IL: Northwestern University Press.

Piaget, J. (1971). Psychology and Epistemology. (A. Rosin, Trans.). New York City, NY: Grossman Publishers.

Rank, O. (1932). Art and the Artist. New York City: Norton \& Company, Inc.

Reynolds, J. (2005). Maurice Merleau-Ponty (1908-1961). Internet Encyclopedia of Philosophy. Retrieved from http:www.iep.utm.edu/Merleau

Sartre, J. P. (1989). Existentialism is a Humanism. Existentialism from Dostoyevsky to Sartre. W. Kaufman, (Ed.). New York: Meridian Publishing Company.

Shakespeare, W. (2011). As You Like It. A. Thompson, D. S. Kastan \& R. Proudfoot, (Eds.). London: Bloomsbury Arden Shakespeare.

Shkolvsky, V. (1917). Art as Technique. In L. T. Lemon and M. J. Reis (Eds.), Russian Formalist Poetics: Four Essays. Lincoln, NE: University of Nebraska Press.

Stanislavski, C. (1936). An Actor Prepares. New York City: Routledge.

Stanislavski, C. (1949). Building a Character. New York City: Routledge/Theatre Arts Books.

Varga, S., \& Guignon G. (2014). Authenticity. Stanford Encyclopedia of Philosophy. Retrieved from http://plato.stanford.edu/entries/authenticity/

Zarilli, P. B. (2007). An Enactive Approach to Understanding Acting. Theatre Journal, 59(4), 635-647. Baltimore, MD: The Johns Hopkins University Press. Retrieved from http://www.jstor.org/stable/25070115 